\title{
Opinie polskich pracowników o wynagrodzeniu minimalnym i ich konteksty w mediach
}

\author{
Jacek Wasilewski \\ Katedra Antropologii Mediów, Wydział Dziennikarstwa, Informacji i Bibliologii, \\ Uniwersytet Warszawski
}

\begin{abstract}
Aleksander Werner
Katedra Prawa Administracyjnego i Finansowego Przedsiębiorstw, Kolegium Nauk o Przedsiębiorstwie, Szkoła Główna Handlowa w Warszawie

Katarzyna Kimla

Katedra Prawa Administracyjnego i Finansowego Przedsiębiorstw, Kolegium Nauk o Przedsiębiorstwie, Szkoła Główna Handlowa w Warszawie
\end{abstract}

Agata Kostrzewa

Wydział Dziennikarstwa, Informacji i Bibliologii, Uniwersytet Warszawski

Celem artykułu jest przedstawienie opinii polskich pracowników dotyczących: minimalnego wynagrodzenia w odniesieniu do roli tego wynagrodzenia jako instrumentu polityki społecznej, treści medialnych o relacji pracownika z pracodawcą oraz poczucia sprawiedliwości społecznej. Analiza naświetla minimalne wynagrodzenie pod kątem sytuacji prawnej, aspektów polityki społecznej oraz narracji pojawiających się w mediach. W artykule zostały przedstawione wyniki badania opinii przeprowadzonego na reprezentatywnej grupie Polaków. Na podstawie ich analizy można wnioskować, że minimalne wynagrodzenie w opinii respondentów powinno być ukształtowane na poziomie pozwalającym 
przeżyć, co może rodzić pytania o jego indywidualizację i dywersyfikację w zależności od indywidualnych cech pracującego.

Słowa kluczowe: sprawiedliwość, sprawiedliwość społeczna, minimalne wynagrodzenie, narracja, polityka społeczna, godna płaca, media

\section{W prowadzenie}

Wynagrodzenie minimalne w kontekście sprawiedliwości ma chronić pracowników w sytuacjach, w której przewaga pracodawców nie zapewnia pracownikom takiej pozycji negocjacyjnej, w której mogliby oni zapewnić sobie byt. Dotyczy to pracowników nie tylko o niskich kwalifikacjach, lecz także o ograniczonej mobilności, zatrudnionych w lokalnych usługach, o słabej orientacji w rynkowej wartości danej pracy i niemożności dłuższych poszukiwań zatrudnienia o satysfakcjonującej płacy (Mortensen, 2005). Państwo, ustalając stawki płacy minimalnej, dąży do zapewnienia podstawowych potrzeb pracujących. W dalszej perspektywie realizuje także takie cele, jak walka z ubóstwem, zapewnienie równej płacy za podobny rodzaj pracy, a także eliminuje praktyki redukcji kosztów płac do poziomu, na którym nie można realnie zaspokajać podstawowych potrzeb. Praca ma zatem w tym ujęciu nie tylko wartość towaru rynkowego, lecz także pełni funkcję społeczną.

Poglądy dotyczące konieczności wprowadzenia minimalnego wynagrodzenia lub wskazań do jego niewprowadzania można przyporządkować do postaw wynikających z dwóch podstawowych metafor opisanych przez G. Lakoffa (2002) w książce pt. Moral Politics. Argumentacja naukowa w dużej mierze dąży do potwierdzenia postawy, jaką ma odbiorca, wynikającej z preferowanego modelu. Autor ten zaproponował dwie kluczowe metafory wyznaczające ramy interpretacyjne dla postaw konserwatywnych i postępowych: konserwatyści posługują się metaforą surowego ojca, a postępowcy - opiekuńczego rodzica (Lakoff, 2011).

W modelu surowego ojca mamy do czynienia z następującą narracją: na świecie czai się zło, trzeba o wszystko rywalizować, co powoduje, że jedni ludzie będą wygrywać, a inni - przegrywać. Istnieje wyraźna opozycja między dobrem a złem. Dlatego jest potrzebny surowy ojciec, który będzie kształtował swoje dzieci tak, aby wybierały dobro i były zdyscyplinowane, inaczej nie są w stanie kierować swoim losem. Dzieci muszą być posłuszne ojcu, gdyż jest on moralnym autorytetem. Jeśli dziecko zachowa się źle (ponieważ wybierze zło), powinna je spotkać kara. Dziecko musi być zdyscyplinowane, bo tylko wtedy osiągnie sukces w świecie zdominowanym przez rywalizację i nie będzie zepsute. Kiedy dziecko jest dorosłe, 
staje się odpowiedzialne za swój los. Ciągła pomoc tylko je rozleniwia, powoduje brak dyscypliny.

W opozycji do surowego ojca istnieje model opiekuńczego rodzica, a w jego centrum jest troska o dziecko. Dziecko jest z natury dobre, dlatego trzeba je wspierać i pomóc mu się rozwijać. To złe otoczenie i warunki nie pozwalają mu rozwinąć potencjału. Świat powinien się stawać coraz lepszym miejscem do życia, co stanie się dzięki uczeniu swojego dziecka opiekuńczości w taki sposób, aby kiedyś to ono przejęło tę opiekuńczą rolę. Model ten w zastosowaniu do polityki skutkuje walką z wykluczeniem, ochroną słabszych i tworzeniem lepszych warunków społecznych. Jak dowodzi G. Lakoff (2011), obie narracje znajdują swoje odzwierciedlenie w sposobie postrzegania przez polityków państwa i społeczeństwa, a ich wynikiem jest popieranie danej polityki gospodarczej. Konserwatyści będą ukazywać związany z płacą minimalną wzrost bezrobocia i inne problemy ekonomiczne, postępowcy będą wskazywać na zabezpieczenia przed wyzyskiem. Minimalne wynagrodzenie jest w tym układzie, z jednej strony, sztucznym zawyżaniem kosztów pracy i wypychaniem z rynku osób słabiej sobie radzących, gdyż nikt ich nie zatrudni i oddala rynek od optymalnej równowagi. $Z$ drugiej strony płaca minimalna ma być zabezpieczeniem najsłabiej sytuowanych.

\section{Prawne kryterium sprawiedliwości minimalnego wynagrodzenia}

Temat płacy minimalnej pojawił się po raz pierwszy u A. Smitha (2007), który zaznaczał, że praca powinna wystarczać na utrzymanie, w przeciwnym wypadku rodziny robotników będę skazane na wymarcie. Regulacje dotyczące płacy minimalnej zostały wprowadzone po raz pierwszy w Nowej Zelandii w 1894 r., by potem stopniowo obejmować kolejne kraje (Krajewska, Krajewski, 2013).

Przegląd minimalnego wynagrodzenia w krajach Unii Europejskiej ukazuje, że nie wszystkie ich systemy prawne przewidują określony ustawowo poziom płacy minimalnej. Bazując na objaśnieniach i danych opublikowanych przez Eurostat, można zauważyć, że w 2018 r. 22 spośród 28 państw członkowskich Unii Europejskiej miało ustaloną płacę minimalną na poziomie krajowym. Do państw, które nie mają takich ustaleń, należą m.in. Dania, Włochy, Cypr, Austria, Finlandia i Szwecja (Eurostat, 2017). Różne są także definicje minimalnego wynagrodzenia w poszczególnych systemach podatkowych.

W Polsce instytucja minimalnego wynagrodzenia za pracę znajduje swoje umocowanie w art. 65 ust. 4 Konstytucji Rzeczpospolitej Polskiej (1997). Wykonanie konstytucyjnego obowiązku implementacji tego rozwiązania do polskiego systemu 
prawnego nastąpiło w drodze ustawy o minimalnym wynagrodzeniu za pracę; przepisy weszły w życie w dniu 1 stycznia 2003 r. (Ustawa ..., 2002).

Ustawowa definicja minimalnego wynagrodzenia odwoływała się w chwili jej wprowadzenia do poziomu wynagrodzenia, poniżej którego nie może zostać ustalona płaca pracownika zatrudnionego w pełnym wymiarze czasu pracy (Ustawa ..., 2002): „niezależnie od posiadanych kwalifikacji, składników wynagrodzenia, jak i szczególnych właściwości i warunków pracy" (Uzasadnienie ..., 2016). Wysokość minimalnego wynagrodzenia była ustalana corocznie w drodze negocjacji w ramach Komisji Trójstronnej do Spraw Społeczno-Gospodarczych (Ustawa ..., 2001). W pierwotnym kształcie przepisów minimalne wynagrodzenie mogło być zróżnicowane długością stażu pracy (obniżone limity minimalnego wynagrodzenia w pierwszym i drugim roku pracy) oraz wykształceniem (obniżone limity minimalnego wynagrodzenia nie miały zastosowania, jeśli pracownik miał wykształcenie wyższe) ${ }^{1}$. Ustawa w kształcie z 2002 r. określała zasady ustalania minimalnego wynagrodzenia wyłącznie w odniesieniu do pracowników, tj. osób, które były zatrudnione na podstawie umowy o pracę, powołania, wyboru, mianowania lub spółdzielczej umowy o pracę (Ustawa ..., 2002). Określenie wysokości minimalnego wynagrodzenia obejmowało wynagrodzenie zasadnicze łącznie z innymi składnikami wynagrodzenia, obejmującymi także dodatki związane z warunkami pracy, premie oraz nagrody.

Ustawa w kształcie z 2002 r. była negatywnie odbierana m.in. z uwagi na dyskryminację umów o innym charakterze (obejmujących np. umowę zlecenie, umowę o dzieło). Zmiana ustawy adresująca m.in. wskazany zarzut została wprowadzona w 2017 r. (Ustawa ..., 2017). Jak wynika z uzasadnienia do ustawy, celem nowelizacji przepisów o minimalnym wynagrodzeniu było uwzględnienie sytuacji, w których osoba, która wykonywała pracę na podstawie umowy cywilnoprawnej, miała ustalone wynagrodzenie na poziomie znacznie niższym od poziomu wynagrodzenia minimalnego przysługującego za pracę w ramach stosunku pracy. Skutkiem były częste przypadki zastępowania umowy o pracę umowami cywilnoprawnymi, których celem było obniżenie kosztów zatrudnienia. Wprowadzone zmiany objęły regulacją minimalnego wynagrodzenia także stawki godzinowe osób wykonujących prace na podstawie określonych umów zlecenia oraz zatrudnione na podstawie umów o świadczenie usług, do których stosuje się przepisy o zleceniu - art. 734 i art. 750 Kodeksu cywilnego (Ustawa ..., 1964). Zakresem regulacji dotyczących płacy minimalnej zostały także objęte tzw. osoby

1 Zgodnie z art. 5 ustawy z dnia 10 października 2002 r. (Ustawa ..., 2002) minimalne wynagrodzenie nie mogło być niższe niż $80 \%$ wysokości ustawowego minimalnego wynagrodzenia w pierwszym roku pracy oraz $90 \%$ wysokości minimalnego wynagrodzenia w drugim roku pracy. 
samozatrudnione. Intencją zmian było przeciwdziałanie nadużyciom tych instytucji. Wymóg minimalnego wynagrodzenia nie dotyczy jednak m.in. stawki godzinowej, jaka jest ustalana w przypadku umów: „jeżeli o miejscu i czasie wykonania zlecenia lub świadczenia usług decyduje przyjmujący zlecenie lub świadczący usługi i przysługuje mu wyłącznie wynagrodzenie prowizyjne" (Ustawa ..., 2017). Celem przyjęcia tego rozwiązania jest wyłączenie przypadków, gdy praca jest świadczona przy zachowaniu pełnej swobody czasu i miejsca realizacji, a ryzyko jej wykonania znajduje się po stronie wykonującego pracę.

Od momentu wprowadzenia przepisów o minimalnym wynagrodzeniu wysokość płacy minimalnej wzrosła z poziomu 800 PLN z 2003 r. (Ustawa..., 2002) do poziomu 2000 PLN w 2017 r. $^{2}$ (Rozporządzenie..., 2016). Przeciętne wynagrodzenie brutto $\mathrm{w}$ gospodarce narodowej liczone $\mathrm{w}$ wielkich przedsiębiorstwach o dużym zatrudnieniu w analogicznym okresie zwiększyło się z poziomu 2201,47 PLN do 4271,51 PLN (Rozporządzenie ..., 2016), tj. wynosi 194\% wartości bazowej ${ }^{3}$. Dominanta, czyli najczęstsze miesięczne wynagrodzenie ogólem brutto otrzymywane przez pracowników zatrudnionych w gospodarce narodowej, wynosiła w październiku 2016 r. 2074,03 PLN, czyli ok. 1511 PLN „na rękę" (GUS, 2018). Z kolei mediana wynagrodzeń wyniosła w tym czasie 3510,67 PLN brutto, czyli 2512 PLN netto. Pracownicy otrzymujący pensję mniejszą lub równą przeciętnemu wynagrodzeniu (tzn. mniej niż 4346,76 PLN) stanowili 66,2\% ogółu pracowników. Płacę minimalną (w badanym 2016 r. było to 1850 PLN) otrzymywało natomiast $9 \%$ ogółu zatrudnionych, czyli co dwunasta osoba mająca umowę o pracę (GUS, 2018).

Wysokość płacy minimalnej rośnie jednak szybciej niż przeciętne wynagrodzenie w gospodarce narodowej. Minimalne wynagrodzenie podlega corocznej waloryzacji o wskaźnik cen (Ustawa ..., 2017). Mechanizm waloryzacji minimalnego wynagrodzenia jest elementem ochrony realnej siły nabywczej wysokości otrzymywanych wynagrodzeń. W tym kontekście, wynagrodzenie minimalne powinno być rozpatrywane przez pryzmat alimentacyjnej funkcji wynagrodzenia za pracę (Biuro Analiz Sejmowych ..., 2012).

2 Wysokość kwoty minimalnego wynagrodzenia w 2018 r. wynosi 2100 PLN zgodnie z treścią Rozporządzenia Rady Ministrów w sprawie wysokości minimalnego wynagrodzenia za pracę oraz wysokości minimalnej stawki godzinowej w 2018 r. (Rozporządzenie ..., 2017). W treści artykułu została wykorzystana wartość minimalnego wynagrodzenia z 2017 r., z uwagi na brak danych dotyczących referencyjnej wysokości przeciętnego wynagrodzenia brutto w gospodarce narodowej w $2018 \mathrm{r}$.

3 Do wyznaczenia przeciętnej pensji pod uwagę są brane tylko wynagrodzenia w firmach, które zatrudniają powyżej 9 osób. A takie przedsiębiorstwa na polskim rynku są w zdecydowanej mniejszości. Większość stanowią małe rodzinne firmy. a te nie są uwzględniane w comiesięcznych ustaleniach GUS. 
Jednym z głównych celów wprowadzenia płacy minimalnej jest dążenie do ograniczenia ubóstwa (Krajewska, Krajewski, 2013). Jednak badania S. Borkowskiej (2005) pokazują, że nie zawsze cel ten jest osiągany, gdyż płacę minimalną pobierają głównie ludzie młodzi, a ich dochody na ogół nie są głównym źródłem dochodów gospodarstwa domowego.

Jak zauważa R. Szarfenberg (2005), zbliżenie wysokości płacy minimalnej do wysokości płacy średniej, a więc odejście od traktowania jej jako pewnego minimum niezbędnego do przetrwania i pójście w stronę standardu średniego życia w Polsce, oznaczałoby zbliżenie rozwiązań polskich do panujących w wielu krajach Unii Europejskiej. Ponadto, takie podejście zapewni zmniejszenie nierówności płacowych, które z kolei w świetle naszych rozważań mogą się przyczynić do zwiększenia poczucia sprawiedliwości (Szarfenberg, 2005).

Co ciekawe, w niektórych krajach Unii Europejskiej nie istnieje pojęcie wynagrodzenia minimalnego $\mathrm{w}$ ramach ustawy, ponieważ jest ono ustalane poprzez negocjacje między pracodawcami a pracownikami różnych branż (Mikuła, 2015). O interesy pracowników dbają wtedy związki zawodowe, jednak w Polsce takie rozwiązanie byłoby trudne do wprowadzenia, gdyż organizacje dbające o interesy pracowników po 1989 r. straciły swoją pozycję. Jak donosi GUS (2015), organizacje te zrzeszają łącznie 1,6 mln członków (z ponad $14 \mathrm{mln}$ pracujących Polaków), co stanowi niewiele ponad 11\% (GUS, 2018). Jest to liczba znacznie poniżej średniej europejskiej. Według danych $\mathrm{z}$ drugiego europejskiego badania przedsiębiorstw (European Company Survey, ECS), w Europie sześciu na dziesięciu pracowników (63\%) należy do uznanych organizacji reprezentujących pracowników w przypadku braku reprezentacji ze strony związków, a społeczne oczekiwanie zapewnienia odpowiedniego wynagrodzenia jest przenoszone na państwo (Eurofound ..., 2009).

\section{Państwo a obywatel - narracje obecne w medialnym dyskursie}

Obecnie dyskusja społeczna toczy się w różnych mediach. W mediach głównego nurtu, które reprezentują zwykle perspektywę i interesy klasy średniej, mamy do czynienia z dyskursem i zasadą sprawiedliwości opartą na racjonalnej efektywności. Natomiast w prasie kierowanej do tzw. niebieskich kołnierzyków ${ }^{4}$, dyskurs skupiony na nierównościach społecznych i wykorzystywaniu przez

4 Pojęcie to zostało po raz pierwszy użyte w 1924 r. w prasie amerykańskiej jako termin obejmujący pracowników fizycznych lub administracyjnych najniższego szczebla. Jego źródłem jest kolor uniformów noszonych przez pracowników fizycznych, w przeciwieństwie do pracowników wyższych szczebli administracji oraz innych pracowników umysłowych, nazywanych „białymi kołnierzykami”. Pojęcie używane pierwotnie w dyskursie medialnym weszło do języka socjologii. Zob. Padavic, Reskin (1990). 
pracodawców pozycji negocjacyjnej do cięcia stawek tak, że przestają oddawać wkład pracy w zysk i nie wiążą płac z potrzebami życiowymi pracowników. Te różnice w podejściu będą odzwierciedlać media adresowane do tych grup. Jeśli dany temat czy perspektywa są pomijane w mediach mainstreamu, znajdują one miejsce na blogach, forach, demotywatorach czy portalach plotkarskich, które odnoszą się często do moralnego wymiaru polityki (Chmielewska-Szlajfer, 2016).

W medialnym dyskursie pojawiają się dwie główne narracje dotyczące relacji między państwem a obywatelem. Pierwsza z nich to narracja pokazująca obywateli jako osoby ciężko pracujące na swoje utrzymanie. W pracy oraz w życiu codziennym cechuje ich uczciwość oraz zaangażowanie. Praca jest dla nich sposobem na utrzymanie rodziny, przedstawianej często jako najważniejsza wartość w życiu. Polacy są w niej pokazywani jako ludzie, którzy nie mają zbyt dużego wpływu na swój los. Sprawczość jest czynnikiem decydującym, albowiem odróżnia ona zwykłych obywateli od tych, którzy decydują o ich losie, tj. od przedstawicieli władzy. Konflikt w tej narracji odbywa się zatem między uczciwym obywatelem, wykonującym prawidłowo swoje obowiązki, a władzą, której uosobieniem są urzędnicy różnego szczebla i różnych instytucji, decydujący o losie ludzi. W swoim działaniu nie kierują się dobrem danego człowieka ani nie rozważają, w jakiej jest on sytuacji, ale decydują zgodnie z literą „bezdusznego” prawa. Warunki życia osób o najniższych dochodach są też zestawianie z tabloidach z uprzywilejowaną pozycją urzędników administracji. Dotyczy to wszystkich instytucji, począwszy od instytucji samorządowych poprzez Zakład Ubezpieczeń Społecznych aż po ministerstwa - organy administracji centralnej (Wasilewski, 2012).

Przykładami takiej narracji jest tekst pt. ZUS jedzie na narty! (2010). Artykuł powstał na początku roku, w okresie zimowym, który wiąże się z większymi kosztami życia (np. ogrzaniem lokalu mieszkalnego). W tekście, z jednej strony, obywatele są przedstawieni jako niepewni swojej przyszłości - nie wiadomo, czy ZUS znajdzie pieniądze na wypłacenie emerytur. Z drugiej zaś są pokazani urzędnicy tej instytucji oraz Premier, pewni swoich racji. Ich słowa nie są jednak przedstawione jako sposób uspokojenia ludzi i zapewnienia im bezpieczeństwa, raczej jako wyrachowanie, za którym kryje się wyzyskiwanie pracowitych Polaków i życie na ich koszt: „Pracownicy ZUS [...] już wkrótce zamiast siedzieć za biurkami, będą szusować po zaśnieżonych stokach Beskidów. I kto to za wszystko zapłaci? Wczasy finansowane są przez samych pracowników oraz z Zakładowego Funduszu Świadczeń Socjalnych. Czyli z naszych pieniędzy, bo przecież ZUS finansowany jest z podatków" (ZUS ..., 2010). Mamy więc bardzo silny motyw wykorzystywania przeciętnego obywatela przez państwo.

$\mathrm{Z}$ kolei w tekście o sugestywnym tytule Państwo mnie okrada! (Rowińska, Woźniak, 2007), traktującym o wprowadzeniu przepisów podwyższających 
składkę ubezpieczeniową dla rencistów prowadzących działalność gospodarczą, można przeczytać: „Urzędnicy ZUS-u nie widzą jednak problemu. Twierdzą, że renciści tylko na tym skorzystają, bo dzięki takiemu rozwiązaniu ich emerytury będą wyższe, a oni sami nabędą prawa do zasiłków i innych świadczeń". W tekście podkreślono zatem brak spojrzenia na sytuację od „ludzkiej” strony, tj. z perspektywy obecnej sytuacji materialnej zwykłego człowieka. Władza (w tym wypadku występująca jako ZUS) staje w opozycji do potrzeb i problemów przeciętnego człowieka, chociaż do tego właśnie została powołana. Co więcej, obraca się przeciwko niemu, podejmując decyzje niekorzystne, utrudniające codzienne funkcjonowanie: „Tymczasem z nowymi przepisami wiążą się kolejne kłopoty. 1 stycznia renciści, którzy chcą dalej dorabiać sobie działalnością gospodarczą, będą musieli... wyrejestrować się z ZUS i zarejestrować na nowo. Czekają ich więc godziny spędzone w kolejkach!" (Rowińska, Woźniak, 2007). W narracji z perspektywy zwykłego obywatela widoczna jest tylko jedna relacja, między człowiekiem a władzą. Niezależnie od tego, czy jest to władza państwowa, czy też władza prywatna (pracodawcy), obywatel znajduje się w hierarchii najniżej.

Drugi typ narracji, który pojawia się w mediach, dotyczy przedstawicieli klasy średniej i występuje w dwóch wersjach - w pierwszej koncentruje się na relacji między właścicielami firm a pracownikami, zaś w drugiej - na relacji między właścicielami firm a państwem.

W pierwszej wersji ukazuje się pracodawców/właścicieli firm jako osoby pracowite i zaradne życiowo, które swoją ciężką pracą i/lub pomysłowością doszły do sukcesu. Ich firma się rozwijała i w związku z tym zatrudniali kolejne osoby. Niestety, po czasie okazuje się, że główną bolączką firmy są właśnie pracownicy. Pracodawca jest zatem przedstawiany w tej narracji jako pełen superlatyw, zwłaszcza w stosunku do pracowników - jest uczciwy i dba o nich, czego przykładem jest przestrzeganie prawa pracy czy używanie takich sformułowań, jak „To ja dałem im pracę", które pokazują, że pracodawca postrzega sam siebie jako pewnego rodzaju wybawienie dla pracownika od bezrobocia (co jest zapewne echem polskiej sytuacji tuż po transformacji - początku lat 90 . XX w. z odznaczających się wysokim odsetkiem bezrobocia). Pracownik tymczasem jest osobą niewdzięczną - albo jest leniwy, albo nie chce pracować i oszukuje, że pracuje (a więc jest wynagradzany za nic), albo okrada pracodawcę z dóbr materialnych (np. znajdujących się biurze lub sprzedawanych w firmie). Pracodawca jest więc pokazywany jako szlachetny człowiek, narażony na nieuczciwe zagrania pracowników, o których dba, skoro ich zatrudnia. Pracownikom w tej narracji jest zarzucana niewdzięczność. Konflikt na linii uczciwy pracodawca-nieuczciwie pracujący pracownik powoduje, że właściciel firmy nie może osiągnąć wymaganego celu, którym jest sukces (rozwój firmy). 
Druga wersja dotyczy konfliktu na linii pracodawca-państwo. Pracodawca - podobnie jak w poprzedniej wersji - jest człowiekiem pracowitym i odpowiedzialnym, szanującym innych. Jego firma nie może się jednak rozwijać lub - co gorsza - przestaje istnieć, ponieważ władza państwowa robi wszystko, żeby mu w tym przeszkodzić. Zabiegi władz mogą odbywać się na poziomie systemowym (np. problemy z zakładaniem firm, niejasne przepisy) lub na poziomie indywidualnym, czego przykładem jest tekst pt. Prezes twierdzi, że firma upada przez fiskusa. Skarbówka: działamy zgodnie z prawem (2017). Jak widać, działanie organów państwa jest podobne do tego z narracji o zwykłym obywatelu - cechuje ją twarde trzymanie się litery prawa oraz przejście od roli podmiotu pomagającego w prowadzeniu działalności gospodarczej do podmiotu utrudniającego prawidłowe funkcjonowanie (Kontrolerzy paraliżuja polskq gospodarkę, 2008).

Warto także zauważyć, iż debata dotycząca sprawiedliwości wynagradzania, odwołująca się do relacji między pracodawcami, pracownikami a państwem, jest pokazywana nie tylko w prasie czy telewizji (a więc w tradycyjnych mediach), lecz także przenosi się do social mediów w postaci wpisów na forach, memów czy stron na Facebooku, co obrazują rysunki 1 i 2.

Jak pokazują przytoczone przykłady na rysunkach 1 i 2, wyraźnie jest zaznaczona hierarchiczność relacji między pracownikami a pracodawcami. Demotywatory pokazują relację pracy jako wyzysk.

Temat niesprawiedliwych zachowań pracowników względem pracodawców jest rzadziej opisywany, a przecież występuje dość często (rysunek 3). Zatem przez pracodawców jest odczuwany brak sprawiedliwości oraz nierówność w liczbie i sposobie pokazywania takich sytuacji. Media społecznościowe dają więc przestrzeń do wyrażenia swojego niezadowolenia nie tylko z zaistniałej sytuacji, lecz także ze sposobu, w jaki jest ona przedstawiana w debacie publicznej.

Narracja od strony zwykłego obywatela jest narracją, którą można nazwać antyinstytucjonalno-syndykalistycznym, w którym $\mathrm{w}$ centrum jest pojęcie nierówności klasowej i wykorzystywanie pozycji społecznej zwłaszcza na linii instytucja-jednostka. Narracja od strony pracodawcy jest narracją folwarczno-liberalną, kiedy konieczne jest bezustanne monitorowanie pracownika, który nie utożsamia się z firmą i jest nastawiony na maksymalizację swojego interesu kosztem pracodawcy. Pracownik jest niczym krnąbrne dziecko i wymaga dyscypliny oraz odpowiedniego wychowania. Narracja folwarczno-liberalna przeważa w mediach i jest nastawiona na własną odpowiedzialność za los i na kontrolę złych pracowników, a płaca minimalna nie jest w niej elementem zapewniania dobrobytu i sprawiedliwości społecznej w zakresie redystrybucji przychodu, tylko pewnego rodzaju minimum, które wszędzie jest już standardem. 
Rysunek 1. Demotywator: „Płaciłbym Ci jeszcze mniej, gdybym tylko mógł”

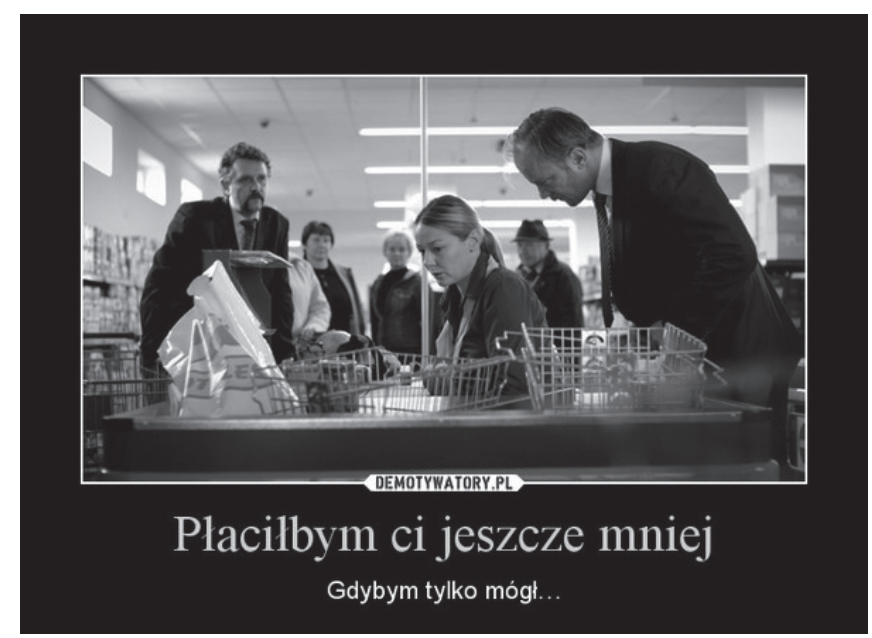

Źródło: Demotywatory.pl (2013).

Rysunek 2. Demotywator: „Chłop dla pana w XVI wieku pracował 104 dni w roku i to był feudalny wyzysk. My na początku XXI wieku pracujemy dla Najjaśniejszej Rzeczypospolitej 164 dni i to jest sprawiedliwość społeczna"

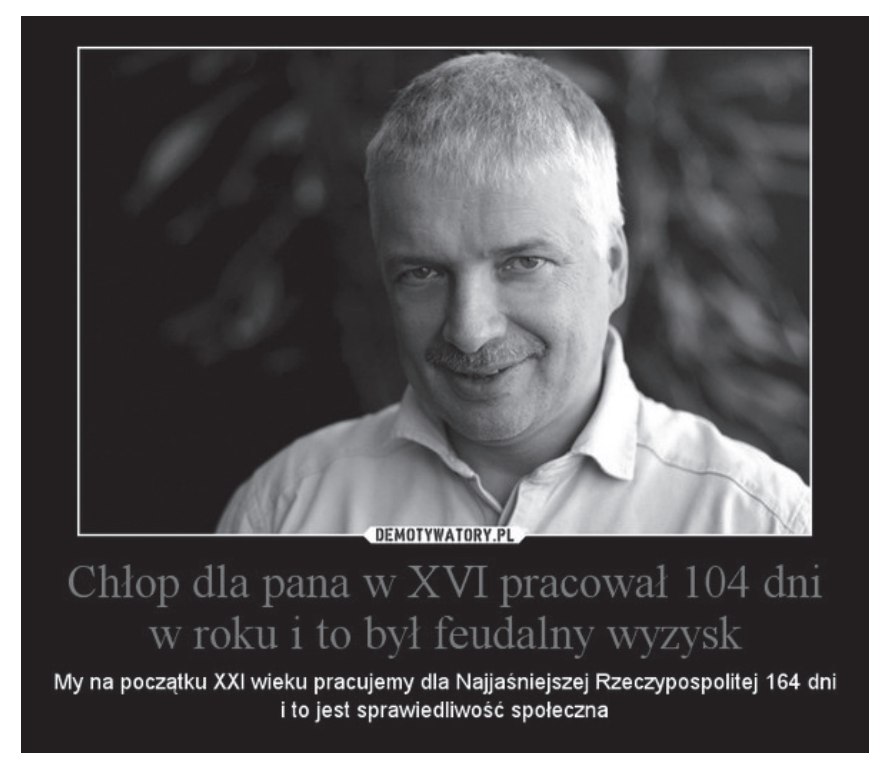

Źródło: Demotywatory.pl (2012). 
Rysunek 3. Screen pt. Temat dla pracodawcy - jak cię okrada pracownik

\title{
Temat dla pradcodawcy - jak cię odpowiedza ten temat okrada pracownik
}

$\begin{array}{llllllll}1 & 2 & 3 & 4 & 5 & \text { Nastepne. }>\end{array}$

\begin{abstract}
DrRock 2007.03.01 [08:21]
Wiele się słyszy, niestety, o nieuczciwych praktykach firm, w których pracowników źle się traktuje, nie wyplaca należnych pieniędzy, zmusza do kłamstw $i$ innych niegodnych zachowań bądź pracy w okrutnych warunkach. Sztandarowym przykładem jest tu choćby słynna Biedronka (czyli siéc sklepów portugalskiej firmy Jeronimo Martins).

ALE TEN TOPIC NIE JEST O TYM. Znacznie mniej popularny temat, to nieuczciwe praktyki pracowników wobec pracodawcy. Zazwyczaj robi się glośno o tym dopiero w skrajnych przypadkach, gdy dochodzi do jawnego przestępstwa - jak choćby telewizyjny przykład z Banku BPH S.A., w którym pracownica zabierała (przeksięgowywała?) pieniądze z kont klientów na swoje własne. Ale ile jest sytuacji mniej doniosłych i nie aż tak wymownych, jakie mają miejsce na codzień i bardzo szkodzą pracodawcom, a więc tym, którzy mogą nam dać prace.
\end{abstract}

Zachẹcam do dyskusji. Piszcie o znanych sobie przypadkach, o tym co sądzicie na ten temat...

Źródło: Temat ... (2007).

W narracjach medialnych sprawiedliwość wynagradzania jest pokazana jako coś, co nie występuje - konflikt między ciężko pracującymi pracownikami a beneficjentami tej ciężkiej pracy jest bardzo wyraźny. System prawny natomiast, podwyższający wysokość płacy minimalnej i uwzględniający wzrost cen (waloryzacja), jest elementem budowania sprawiedliwości wynagradzania. Widać więc wyraźny rozdźwięk między rozwiązaniami prawnymi a poczuciem sprawiedliwości w społeczeństwie.

\section{Pojęcie godnej płacy w polskim dyskursie}

Jako dyskurs rozumie się w tym wypadku praktykę wypowiadania się na dany temat $\mathrm{w}$ różnych aspektach (społecznym, prawniczym, medialnym, zawierającym historię o ludziach). Dyskurs w ujęciu T. van Dijka zawiera w sobie definicje pojęć, a także reguły pojawiania się pewnych treści dotyczących danego tematu (Dijk van, 2001). Dyskurs wokół tematu zmienia się w czasie w zależności od tego, który podmiot społeczny uzyskuje lub traci dominującą pozycję. 
Ujęcie reprezentowane $\mathrm{w}$ prawie, czyli alimentacyjna funkcja minimalnego wynagrodzenia, ma związek z medialnym pojęciem godnej płacy, które wchodzi $\mathrm{w}$ relację z prawnym pojęciem wynagrodzenia minimalnego. Godna płaca jako pojęcie i postulat jest obecna w postulatach populizatorskich wielu ruchów politycznych czy społecznych. Począwszy od 21 postulatów Solidarności z 1980 r., w których punkt 8. dotyczył podniesienia zasadniczego uposażenia każdego pracownika o 2000 PLN na miesiąc jako rekompensatę dotychczasowego wzrostu cen, a punkt 9. - zagwarantowania automatycznego wzrostu płac równolegle do wzrostu cen i spadku wartości pieniądza. Ponownie w dyskursie politycznym pojawił się postulat godnej płacy w postulatach A. Leppera - jako fundament godnego życia, a następnie w kampanii PiS.

Z kilku przykładów związanych z użyciem postulatu godnej płacy można zauważyć, że godność płacy odwołuje się przede wszystkim do egalitaryzmu zapewnienie odpowiednich warunków życia poprzez godną płacę ma obejmować wszystkich Polaków, w przeciwieństwie do oceny sytuacji, jaką wysuwali postulujący w chwili tworzenia programów politycznych, kiedy to według nich godnie żyła tylko elita. Stąd takie hasła, jak Partii Razem: Polska dla milionów, nie dla milionerów; Człowiek, Rodzina, Praca, Godne życie oraz Partia z przyszłościq czy Samoobrony Każdy człowiek jest ważny.

\section{Ocena minimalnego wynagrodzenia w świetle badań opinii}

Badanie opinii zrealizowane przez zespół badawczy złożony przez przedstawicieli Szkoły Głównej Handlowej w Warszawie i Uniwersytetu Warszawskiego miało na celu m.in. powiązanie dochodów i potrzeb życiowych ${ }^{5}$. Badanie przeprowadzono w wyniku realizacji projektu badawczego nr 2016/21/B/HS4/02992 pt. Sprawiedliwość wynagradzania, finansowanego ze środków Narodowego Centrum Nauki. Na potrzeby niniejszego artykułu zostały przeanalizowane odpowiedzi respondentów w zakresie ich oceny minimalnego wynagrodzenia. Respondenci odpowiadali na pytania dotyczące zasadności stosowania takiego rozwiązania oraz oceny czynników, które mogłyby wpływać na przyznawanie minimalnego wynagrodzenia czy jego wysokość.

Zgadza się ze stwierdzeniem, że każdy dorosły, bez względu na to, czy pracuje, czy też nie, powinien dostawać tyle pieniędzy, by mógł pokryć podstawowe

5 Badanie zostało przeprowadzone w listopadzie 2017 r. na reprezentatywnej próbie pracujących Polaków ( $N=1067)$ techniką telefoniczną CATI (Computer Assisted Telephone Interviewing) przez firmę Kantar MillwardBrown. Dobór respondentów był losowy. 
Rysunek 4. Odpowiedzi na stwierdzenie: „Każdy dorosły, bez względu na to, czy pracuje, czy też nie, powinien dostawać pieniądze, które pozwalają mu pokryć podstawowe wydatki życiowe"

\section{OGÓ£EM}

Nie wiem \trudno powiedzieć

Zdecydowanie się zgadzam

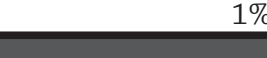

$1 \%$
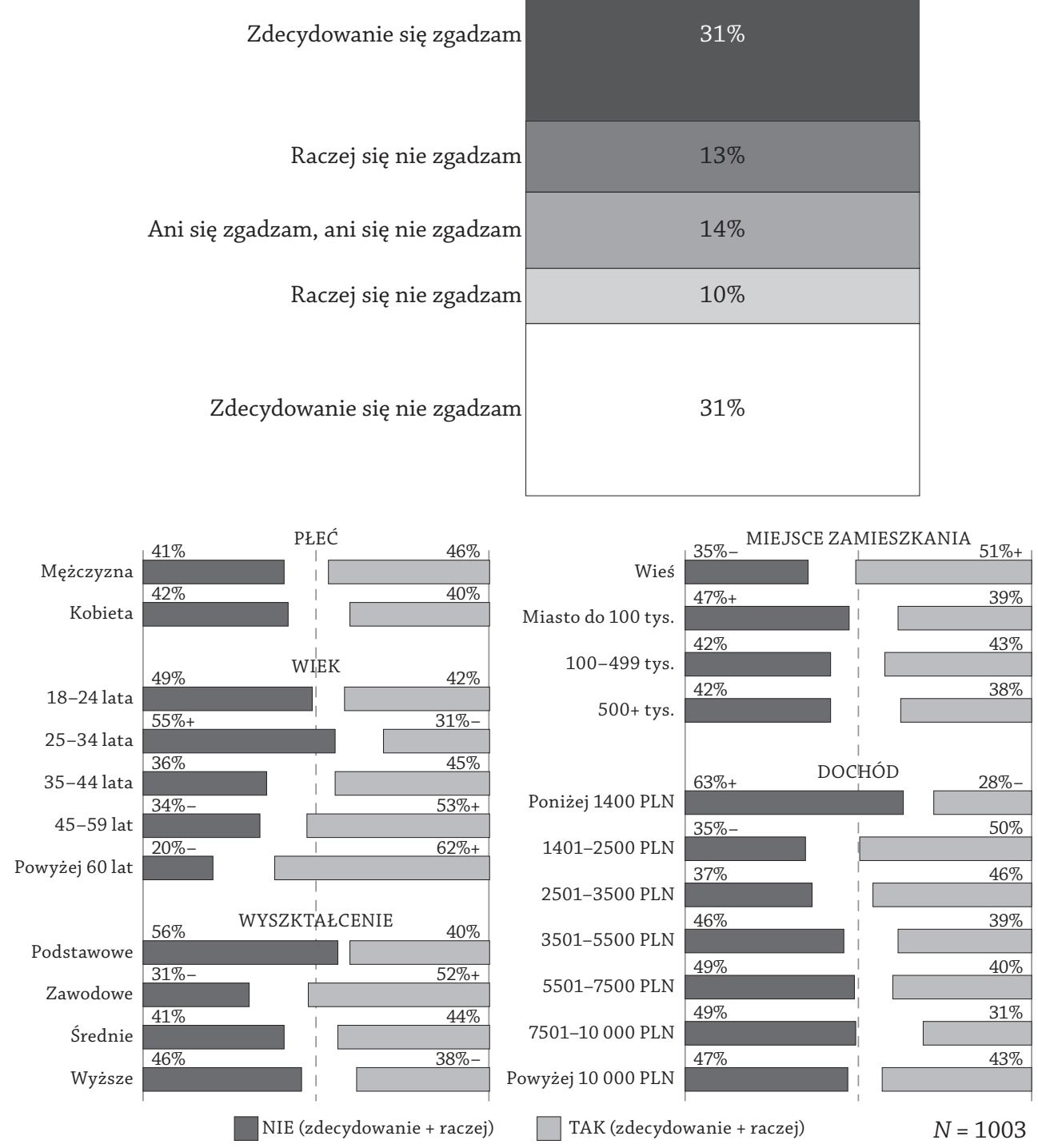

Uwaga: $+\backslash$ - różnice statystycznie w stosunku do wszystkich respondentów istotne na poziomie 95\%.

Źródło: badanie Kantar MillwardBrown. 


\section{Rysunek 5. Odpowiedzi na pytanie: „Czy kwota minimalnego wynagrodzenia} powinna być na poziomie pozwalającym przeżyć?”
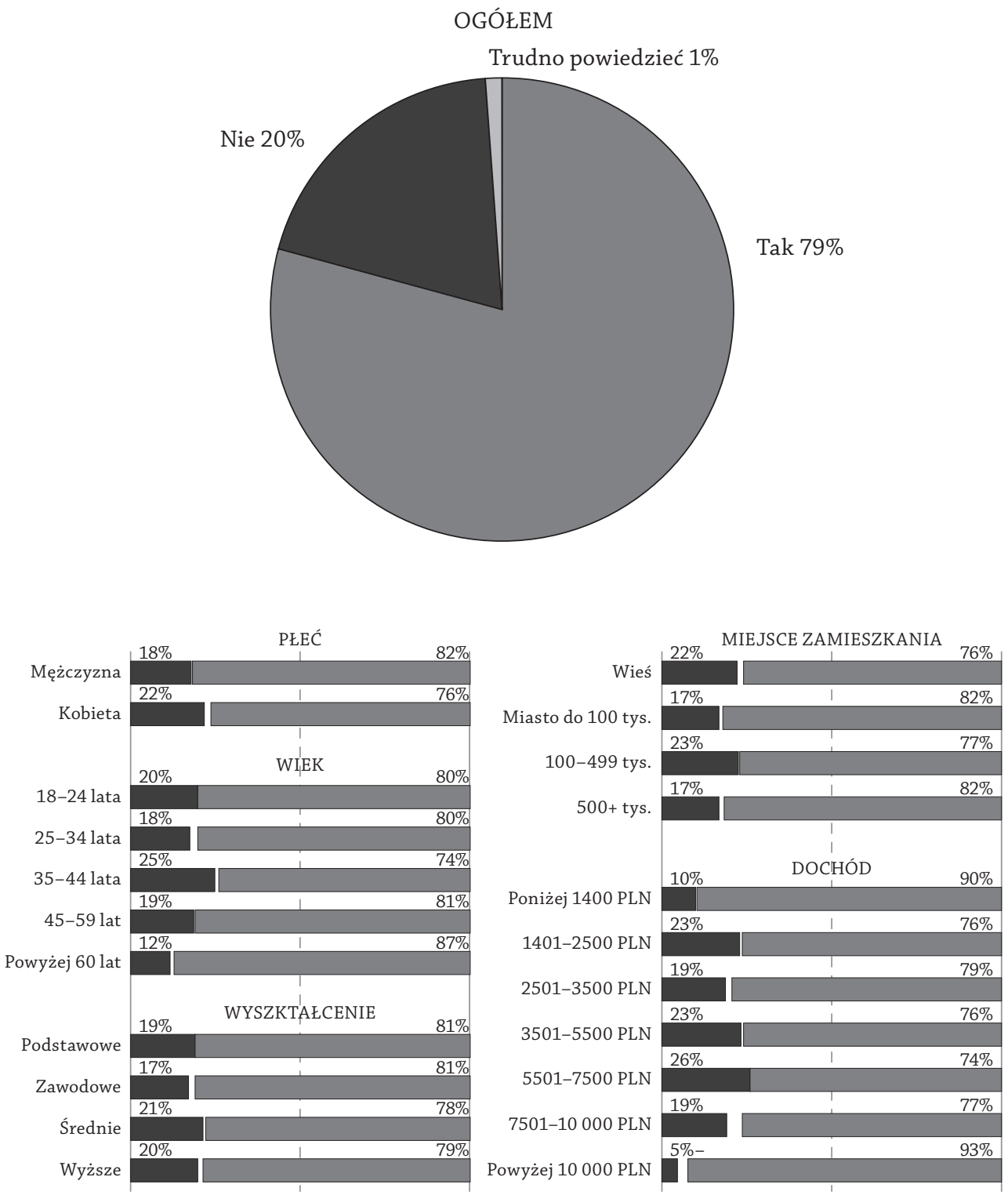

$N=827$

Uwaga: +\- różnice statystycznie w stosunku do wszystkich respondentów istotne na poziomie 95\%.

Źródło: badanie Kantar MillwardBrown. 
Rysunek 6. Odpowiedzi na pytanie: „Czy kwota minimalnego wynagrodzenia powinna być uzależniona od sytuacji rodzinnej?”
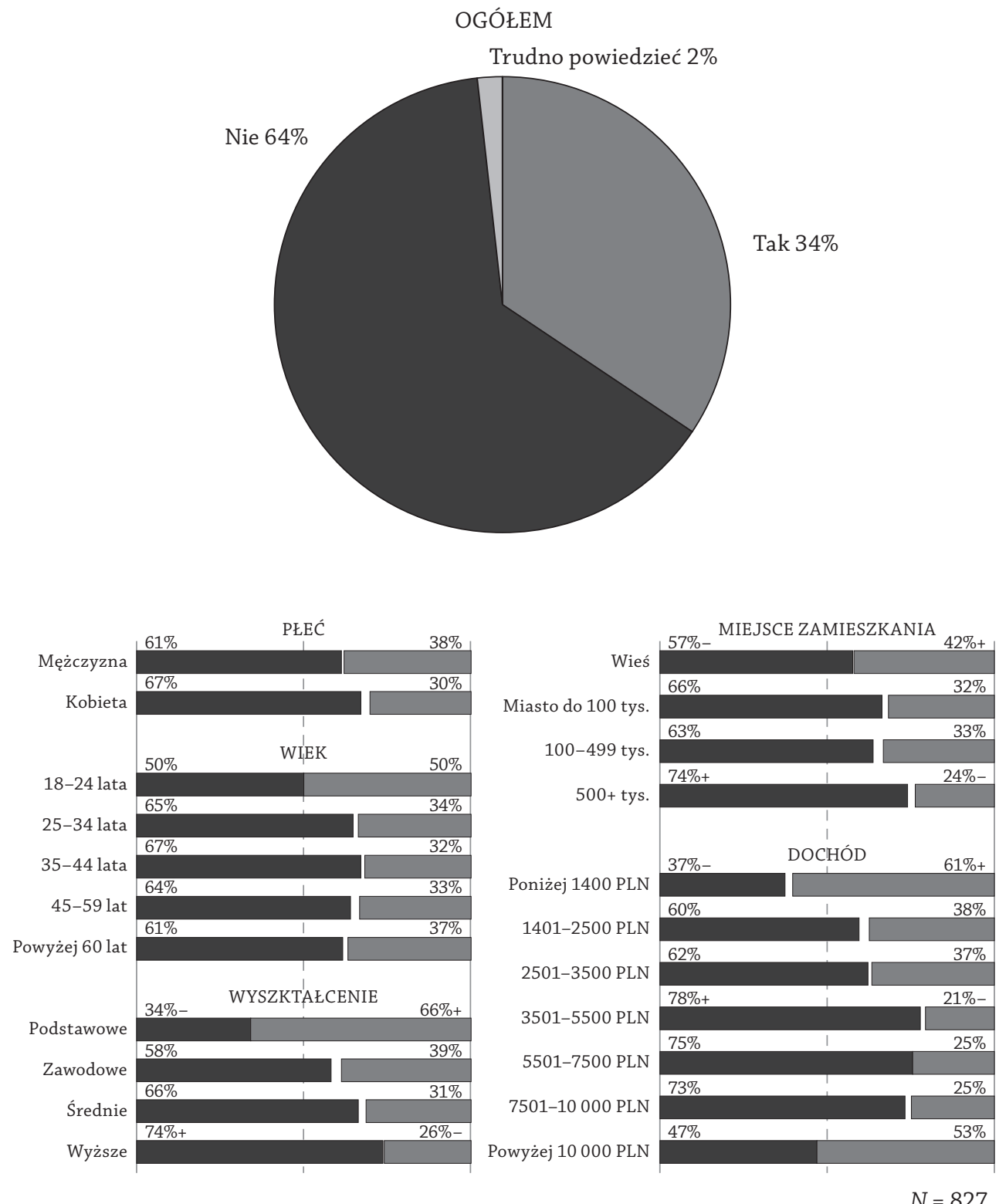

Uwaga: +\- różnice statystycznie w stosunku do wszystkich respondentów istotne na poziomie 95\%.

Źródło: badanie Kantar MillwardBrown. 
wydatki życiowe, 36\% respondentów (rysunek 4). Ze stwierdzeniem tym nie zgadza się ponad połowa badanych (51\%), z czego aż 39\% zdecydowanie, zaś $13 \%$ respondentów nie ma na ten temat zdania.

To, co różnicuje odpowiedzi, jest poziom wykształcenia i wysokość dochodu respondentów. Osoby z wykształceniem wyższym, które wiąże się często z efektywnością wykonywanej pracy, w mniejszym stopniu niż inne zgadzały się na to, by pieniądze otrzymywano bez względu na świadczenie pracy. Odpowiada to średnioklasowej narracji o życiu, w której człowiek sam odpowiada za swój los, tak więc państwo nie powinno przyjmować roli opiekuńczej względem obywatela. Odwrotnie ma się rzecz z dochodami - im niższe, tym więcej osób uważa, że pieniądze powinny być przyznawane ze względu na potrzeby życiowe, a nie na wartość samej pracy.

Dużo większe poparcie ma idea powiązania wysokości minimalnego wynagrodzenia z minimalnym poziomem pozwalającym przeżyć (rysunek 5). Jak widać, idea płacy minimalnej nie jest godną płacą, ale płacą rzeczywiście progową i te jej funkcje są powszechnie akceptowane społecznie.

Podobnie akceptujący rozkład opinii dotyczy samej idei wynagrodzenia minimalnego i pracy. Osoby zarabiające blisko mediany wynagrodzeń w największym stopniu zgadzały się ze stwierdzeniem, że każdy, kto pracuje, powinien dostawać co najmniej minimalne wynagrodzenie, przy czym była to różnica statystycznie istotna w stosunku do innych grup. Niezależnie od cech demograficznych respondentów można zauważyć, że kwestia świadczenia jest częściej powiązana z wykonywaniem przez daną jednostkę pracy niż z zapewnieniem jej świadczenia niejako $\mathrm{z}$ automatu. Świadczenie jest zatem postrzegane jako odpowiedź na działanie człowieka, a nie ma wynikać z powinności opiekuńczej państwa.

Nie dotyczy to grupy najsłabiej wykształconych. Na pytanie, czy kwota minimalnego wynagrodzenia powinna być uzależniona od sytuacji rodzinnej, 66\% osób z podstawowym wykształceniem odpowiedziało twierdząco, zaś tylko $26 \%$ osób z wykształceniem wyższym (rysunek 6). Co ciekawe, zgadzała się z tą opinią ponad połowa osób o najniższym dochodzie i o dochodzie najwyższym (poniżej 1400 PLN i powyżej 10000 PLN), co wskazuje na doświadczenie rodzinnych obciążeń konsumpcyjnych także w grupie najwyżej zarabiających.

Ponad 4/5 respondentów podziela pogląd, że wynagrodzenie minimalne powinno dotyczyć pracowników niezależnie od tego, czy są zatrudnieni na etat, czy też nie. Różnice pomiędzy grupami nie są istotne statystycznie. 


\section{Podsumowanie}

Minimalne wynagrodzenie jest elementem sprawiedliwości wynagradzania. Jego rolą przez długi czas było zapewnienie minimalnych środków, które pozwolą osobie pracującej na przeżycie. Obecnie, biorąc pod uwagę rosnącą wysokość minimalnego wynagrodzenia, można zauważyć, że powoli pozwala ono na zabezpieczenie większej liczby potrzeb.

Godna płaca jest postulatem politycznym, który nie ma poparcia społecznego, chociaż dominanta dochodów uzyskiwanych z pracy jest na niskim poziomie.

Narracje medialne są zbudowane na konflikcie między pracownikami, pracodawcami a przedstawicielami urzędów publicznych. Pokazywanie tego konfliktu podsyca poczucie krzywdy i podkreśla nierówności społeczne. Warto jednak zwrócić uwagę, iż w znacznej mierze jest piętnowana kwestia wadliwego sposobu zarządzania (np. nagród dla urzędników), niskiego kapitału społecznego (którego przykładem jest małe zaufanie społeczne ludzi) czy niska wydolność państwa. Tak więc nie jest to do końca kwestia realnego poczucia niesprawiedliwości wynagradzania, ale ogólnego poczucia niesprzyjającej sytuacji pracy w skali mikro i makro.

O politycznym wykorzystaniu odejmowania uprzywilejowanym świadczą ostatnie ruchy rządzących, np. wypowiedź Prezesa Prawa i Sprawiedliwości, J. Kaczyńskiego, o obniżeniu wynagrodzeń posłom i innym politykom (Zuchowicz, 2008) czy decyzja akcjonariuszy PKN Orlen o obniżeniu o połowę maksymalnej pensji prezesa spółki (Kublik, 2017). Pokazuje to, że temat wysokości wynagrodzeń nadal wzbudza społeczne emocje, a co za tym idzie - istnieje duża szansa, że nieraz powróci jako temat debaty, która może się przełożyć na kolejne rozwiązania prawne.

\section{Bibliografia}

Biuro Analiz Sejmowych Kancelarii Sejmu (2012). Minimalne wynagrodzenie za pracę. Druk sejmowy nr 28. http://orka.sejm.gov.pl/wydbas.nsf/0/f255034b81806511c 1257a070039a7c3/\$file/ppc_1-2012.pdf (25.06.2018).

Borkowska, S. (2005). Płaca minimalna a ograniczanie ubóstwa. W: A. Ząbkowicz i in. (red.), Polityka społeczna. Wybrane problemy. Warszawa: IPiSS, 89-96.

Chmielewska-Szlajfer, H. (2016). Votes and Visibility on Social Media. The Case of Poland's 2015. Surprising Presidential Elections. Third ISA Forum of Sociology. Vienna, 10-14.07.2016. https://www.academia.edu/27077770/Votes_and_Visibility_on_ 
Social_Media._The_Case_of_Polands_2015_Surprising_Presidential_Elections (1.07.2018).

Demotywatory.pl (2012). https://demotywatory.pl/3976239/Chlop-dla-pana-w-XVIpracowal-104-dni-w-roku-i-to-byl-feudalny-wyzysk (1.07.2018).

Demotywatory.pl(2013).https://demotywatory.pl/user/SeNsEi91/ulubione/page/347 (1.07.2018)

Dijk van, T. (2001). Dyskurs jako struktura i proces. Warszawa: Wydawnictwo Naukowe PWN.

Eurofound ogłasza raport z drugiego europejskiego badania przedsiębiorstw (2009). okap. org.pl. http://okap.org.pl/aktualnosci/eurofound-oglasza-raport-z-drugiego-euro pejskiego-badania-przedsiebiorstw/ (1.07.2018).

Eurostat (2017). Minimum wages. Ec.europa.eu. http://ec.europa.eu/eurostat/cache/ metadata/en/earn_minw_esms.htm (1.07.2018).

Golnau, W. (2007). Znaczenie płacy minimalnej dla funkcjonowania rynku pracy. Gdańsk: Wydawnictwo Uniwersytetu Gdańskiego.

GUS (2018). Rocznik Statystyczny Pracy 2017. Warszawa. http://stat.gov.pl/obszary-tematyczne/roczniki-statystyczne/roczniki-statystyczne/rocznik-statystyczny-pracy-2017,7,5.html (1.07.2018).

GUS (2015). Związki zawodowe w Polsce w 2014 r. Notatka informacyjna. Warszawa. https://stat.gov.pl/files/gfx/portalinformacyjny/pl/defaultaktualnosci/5490 /10/1/1/notatka_zz_1007_ost.pdf (1.07.2018).

Konstytucja Rzeczpospolitej Polskiej z dnia 2 kwietnia 1997 r. Dz.U. Nr 78, poz. 483.

Kontrolerzy paraliżuja polskq gospodarkę (2008). finanse.wp.pl. https://finanse.wp.pl/ kontrolerzy-paralizuja-polska-gospodarke-6114145878362241a (5.09.2018).

Krajewska, A., Krajewski, S. (2013). Kontrowersje wokół pracy minimalnej. IX Kongres Ekonomistów Polskich. http://www.pte.pl/kongres/referaty/Krajewska\%20 Anna,\%20Krajewski\%20Stefan/Krajewska\%20Anna,\%20Krajewski\%20Stefan\%20 -\%20KONTROWERSJE\%20WOK\%C3\%93\%C5\%81\%20P\%C5\%81ACY\% 20 MINIMALNEJ.pdf (5.08.2018).

Kublik, A. (2017). Tchórzewski uciął kominy płacowe w Orlenie. wyborcza.pl. http://wyborcza.pl/7,155287,21287107,tchorzewski-ucial-kominy-placowe-w-orlenie.html (1.07.2018).

Kulisa, B., Sierpińska, M. (2016). Wzrost gospodarczy a płace minimalne w Polsce. Finanse, Rynki Finansowe, Ubezpieczenia, 4(82/1), 759-768.

Lakoff, G. (2002). Moral Politics: How Liberals and Conservatives Think. Chicago: University of Chicago Press.

Lakoff, G. (2011). Nie myśl o słoniu! Jak język kształtuje politykę. Warszawa: Oficyna Wydawnicza Łośgraf.

Mikuła, A. (2015). Wynagrodzenie minimalne a ubóstwo, nierówności dochodowe i bezrobocie w Polsce. Zeszyty Naukowe SGGW w Warszawie. Ekonomika i Organizacja Gospodarki Żywnościowej, 112, 87-100. 
Mortensen, D.T. (2005). Wage Dispersion: Why Are Similar Workers Paid Differently? Industrial \& Labour Relations Review, 58, 659-663.

Padavic, I., Reskin, B.F. (1990). Men's Behavior and Women's Interest in Blue-Collar Jobs. Social Problems, 4(37), 613-628.

Prezes twierdzi, że firma upada przez fiskusa. Skarbówka: działamy zgodnie z prawem (2017). tvnbiz.pl. https://tvn24bis.pl/z-kraju,74/spolka-mgm-sklada-wniosek-oupadlosc-bo-fiskus-zajal-jej-35-mln-zl,731101.html (1.07.2018).

Rowińska, A., Woźniak, A. (2007). Państwo mnie okrada! Se.pl. https://www.se.pl/wiadomosci/polska/panstwo-mnie-okrada-aa-mo43-B7km-SeAK.html (1.07.2018).

Rozporządzenie Rady Ministrów z dnia 9 września 2016 r. w sprawie wysokości minimalnego wynagrodzenia za pracę w 2017 r. Dz.U. poz. 1456.

Rozporządzenie Rady Ministrów z dnia 12 września 2017 r. w sprawie wysokości minimalnego wynagrodzenia za pracę oraz wysokości minimalnej stawki godzinowej w 2018 r. Dz.U. poz. 1747.

Smith, A. (2007). Badania nad naturą i przyczynami bogactwa narodów. Warszawa: Wydawnictwo Naukowe PWN.

Suchecki, B. (1999). Narzędzia kształtowania dochodu godziwego w Polsce. W: S. Borkowska (red.), Wynagrodzenia godziwe. Koncepcje i pomiar. Warszawa: IPiSS, 155-188.

Szarfenberg, R. (2005). Kontrowersje wokót podniesienia płacy minimalnej. http://rszarf. ips.uw.edu.pl/pdf/placmin.pdf (1.07.2018).

Średnia pensja kontra mediana i dominanta, czyli ile tak naprawdę zarabiaja Polacy (2018). Forsal.pl. http://forsal.pl/artykuly/1105759,srednia-pensja-mediana-i-dominant a-wynagrodzen-w-polsce-ile-naprawde-zarabiamy.html (1.07.2018).

Temat dla pracodawcy - jak cię okrada pracownik (2007). kafeteria.pl. https://f.kafeteria.pl/temat/f14/temat-dla-pracodawcy-jak-cie-okrada-pracownik-p_3420708 (1.07.2018).

Ustawa z dnia 23 kwietnia 1964 r. - Kodeks cywilny. Dz.U. Nr 16, poz. 94 z późn. zm. Ustawa z dnia 6 lipca 2001 r. o trójstronnej Komisji do Spraw Społeczno-Gospodarczych i wojewódzkich komisji dialogu społecznego. Dz.U. Nr 100, poz. 1080.

Ustawa z dnia 10 października 2002 r. o minimalnym wynagrodzeniu za pracę. Dz.U. Nr 200, poz. 1679.

Ustawa z dnia 7 kwietnia 2017 r. o minimalnym wynagrodzeniu za pracę. Dz.U. poz. 847.

Uzasadnienie do ustawy z dnia 17 sierpnia 2016 r. o zmianie ustawy o minimalnym wynagrodzeniu za pracę oraz niektórych innych ustaw. Dz.U. poz. 1265.

Wasilewski, J.(2012). Język tabloidów - jego źródła i mechanizmy. W: A. Markowski, R. Pawelec (red.), Oblicza polszczyzny. Seria: Ojczysty - dodaj do ulubionych. Warszawa: Wydawnictwo: Narodowe Centrum Kultury,169-181.

Zuchowicz, K.(2018). W moim przypadku 20 procent to około 2600 zł. Samorzadowcom z PiS też nie podobają się obniżki sterowane z Warszawy. Natemat.pl, 09.04. http:// 
natemat.pl/234901,wojt-burmistrz-prezydent-obnizki-pensji-co-na-to-wlodarze -pis (1.07.2018).

ZUS jedzie na narty! (2010). Fakt.pl, 10.01.2010. http://www.fakt.pl/wydarzenia/polityka/zus-jedzie-na-narty/jbmlef0 (1.07.2018).

\section{Summary}

\section{Opinions of Polish Employees on Minimum Remuneration and Their Contexts in Media}

The purpose of the article is to show the minimum remuneration in relation to the principle of equitable remuneration. The analysis shows the minimum salary in terms of the legal situation, social policy aspects and media narratives. Finally are presented the results of a survey conducted on a representative group of Poles that show that the minimum wage in the respondents' opinion should be at a level allowing them to survive.

Keywords: justice, social justice, minimum wage, narrative, social policy, decent salary

\section{Dr hab. Aleksander Werner, prof. SGH}

Pracownik Katedry Prawa Administracyjnego i Finansowego Przedsiębiorstw Szkoły Głównej Handlowej, gdzie od kilku prowadzi wykłady m.in. z prawa podatkowego, prawa ochrony konkurencji, prawa rynku kapitałowego oraz prawa gospodarczego. Jest autorem wielu publikacji z zakresu swojej specjalizacji. Obronił w SGH pracę doktorską pt. Pomoc publiczna dla przedsiębiorców a ochrona konkurencji. Przewód habilitacyjny przeprowadzony na Wydziale Prawa Uniwersytetu w Białymstoku dotyczył prawa podatkowego (monografia habilitacyjna pt. Adekwatność sytuacji prawnopodatkowej polskich przedsiębiorców dla ich roli w gospodarce. 2013. Warszawa: SGH).

\section{Dr hab. Jacek Wasilewski}

Doktor habilitowany nauk politycznych. Pracę doktorską pt. Retoryka dominacji obronił w 2004 r. na Wydziale Dziennikarstwa i Nauk Politycznych UW. Habilitację uzyskał w 2014 r. na podstawie pracy pt. Opowieści o Polsce. Retoryka narracji. 
Od roku 2011 kieruje specjalnością Dokumentalistyka, której celem jest rozwijanie multimedialnych dziennikarskich form narracyjnych. Członek Komisji Żywego Słowa Rady Języka Polskiego. Zajmuje się ekspertyzami dla sądów, KRRiTV, stacji medialnych i innych podmiotów publicznych. Współpracował z Krajową Szkołą Sędziów i Prokuratorów, prowadził zajęcia z retoryki w Okręgowej Izbie Radców Prawnych w Warszawie.

\section{Mgr Katarzyna Kimla}

Studentka III roku studiów doktoranckich w Szkole Głównej Handlowej w Warszawie. Współpracuje z Katedrą Prawa Administracyjnego i Finansowego Przedsiębiorstw Szkoły Głównej Handlowej. Jej zainteresowania naukowe skupiają się przede wszystkim na zagadnieniach prawa podatkowego, ekonomicznej analizy prawa regulacji podatkowych oraz wpływie podatków na funkcjonowanie przedsiębiorstw w gospodarce. Dysertacja doktorska dotyczy problemu przerzucalności ekonomicznego ciężaru opodatkowania na podmioty trzecie w perspektywie indywidualnych rozstrzygnięć organów podatkowych i sądów administracyjnych.

\section{Mgr Agata Kostrzewa}

Studentka I roku studiów doktoranckich na Wydziale Dziennikarstwa Informacji i Bibliologii Uniwersytetu Warszawskiego. Jej zainteresowania naukowe skupiają się na analizie dyskursu medialnego, ze szczególnym uwzględnieniem narracji i argumentacji dotyczącej polityki społecznej, zwłaszcza w zakresie edukacji, polityki rodzinnej, polityki rynku pracy, oraz nierówności społecznych, równouprawnienia i dyskryminacji. 